\title{
Regional Financial Integration in the GCC
}

\author{
Raphael Espinoza, Ananthakrishnan \\ Prasad and Oral Williams
}




\title{
IMF Working Paper
}

Middle East and Central Asia Department

\section{Regional Financial Integration in the GCC}

Prepared by Raphael Espinoza, Ananthakrishnan Prasad, and Oral Williams ${ }^{1}$

Authorized for distribution by Abdelhak Senhadji

April 2010

\begin{abstract}
This Working Paper should not be reported as representing the views of the IMF.

The views expressed in this Working Paper are those of the author(s) and do not necessarily represent those of the IMF or IMF policy. Working Papers describe research in progress by the author(s) and are published to elicit comments and to further debate.
\end{abstract}

We investigate the extent of regional financial integration in the member countries of the Gulf Cooperation Council. The limited volume data available suggests that regional integration is non-negligible. Bahrain and Kuwait investments especially are oriented towards the region. The development of stock markets in the region will also improve the extent of financial integration. Interest rate data shows that convergence exists and that interest rate differentials are relatively short-lived - especially compared to the ECCU, another emerging market region sharing a common currency. Equities data using cross-listed stocks confirms that stock markets are fairly integrated compared to other emerging market regions, although financial integration is hampered by market illiquidity.

JEL Classification Numbers: F32, F36, G15

Keywords: Interest rate convergence, sigma-convergence, beta-convergence, arbitrage opportunity, cross-listing, regional capital flows

Author's E-Mail Address: respinoza@imf.org; aprasad@imf.org; owilliams2@imf.org

\footnotetext{
${ }^{1}$ The authors thank Mohsin Khan, Klaus Enders, May Khamis, Gabriel Sensenbrenner, John Sfafianakis, Anthony Cypriannou, Randa Khoury, and the participants at the MCD Seminar and the Eleventh Mediterannean Research Meeting for their insightful comments. All errors and omissions remain ours.
} 
I. Introduction

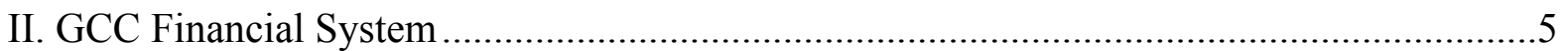

A. Macroeconomic and Monetary Environment ....................................................... 5

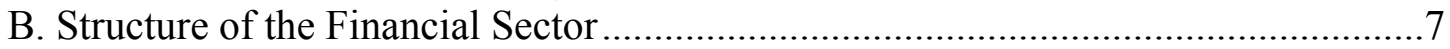

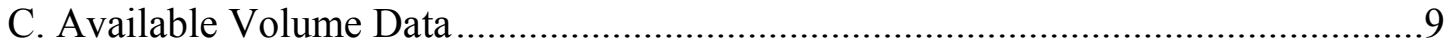

III. Price Data: Interest Rate and Cross-Listings ....................................................... 12

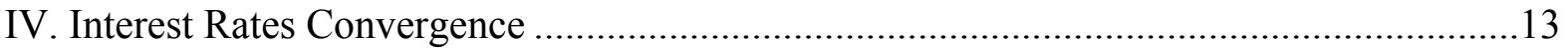

A. Beta Convergence and Sigma Convergence .................................................13

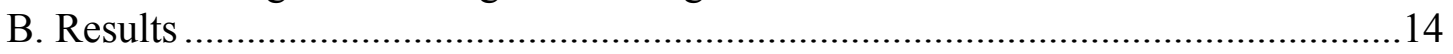

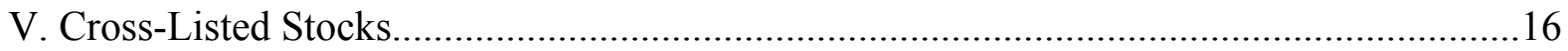

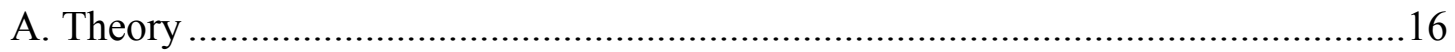

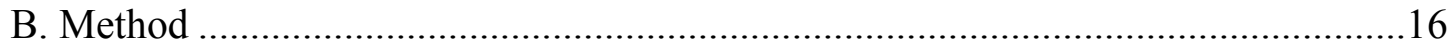

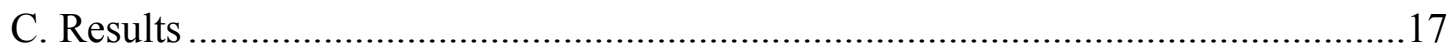

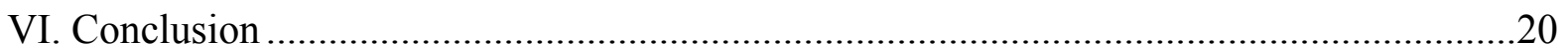

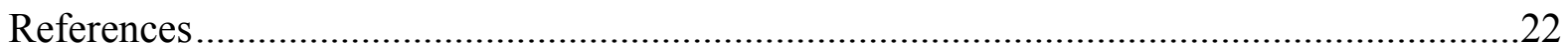

Figures

1. Credit Default Swaps on Five-Year Senior ................................................................6

2. Nominal Exchange Rates and Interbank Interest Rates .................................................. 7

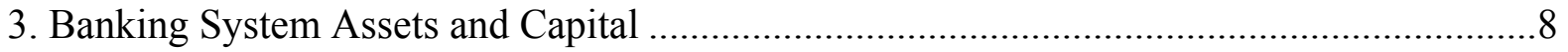

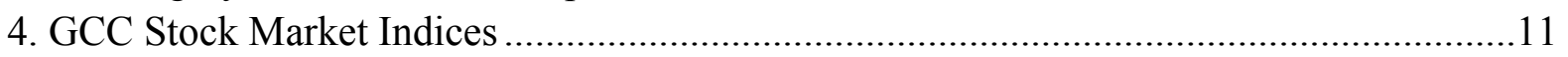

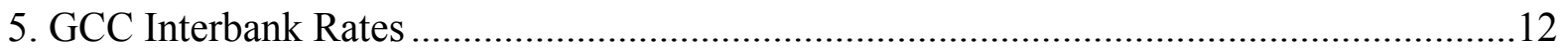

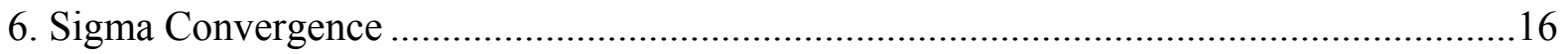

7. Selected Cross-Listed Stocks in the GCC.................................................................. 18

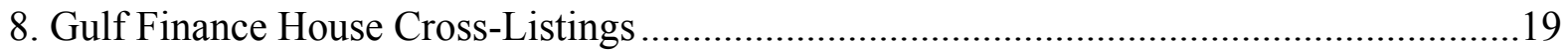

Tables

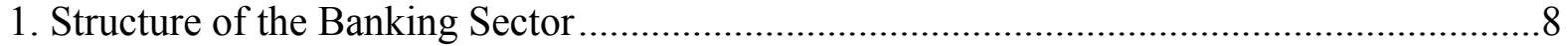

2. Loans, Deposits and Foreign Assets and Liabilities ...................................................... 9

3. Restrictions on Resident and Nonresident Deposit Accounts......................................... 10

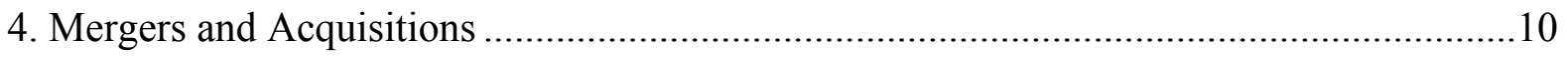

5. Portfolio Investment Asset in GCC Partner - Equity........................................................11

6. Portfolio Investment Asset in GCC Partner - Long-Term Debt Securities ........................11

7. Prudential Measures, Latest Available Data ....................................................................24

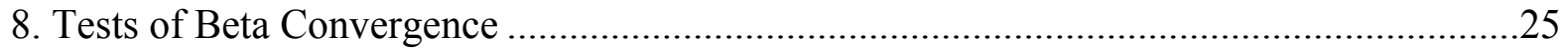

9. ECCU: T-Bill Rates Tests of Beta Convergence ............................................................26

10. ECCU: Deposit Rates Tests of Beta Convergence ..........................................................2 


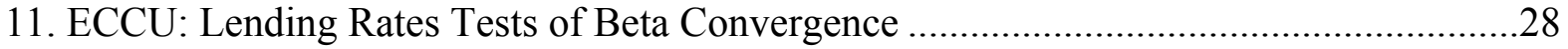

12. Selected Sources and Destination of Cross-Listings ..................................................29

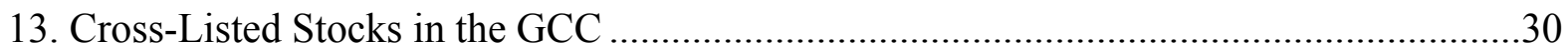

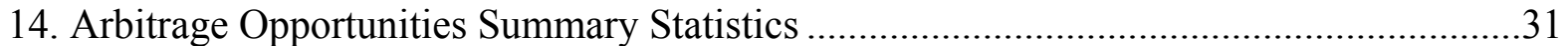

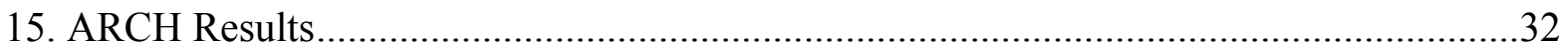

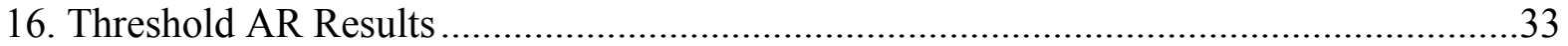




\section{INTRODUCTION}

We assess the extent of regional financial integration in the countries of the Cooperation Council of the Arab States of the Gulf (GCC) ${ }^{2}$ by looking at the structure of the financial system and using interest rate and equity price data. While various papers (e.g. Adam et al. (2002) and Baele et al. (2004)) have investigated financial integration in the Euro area, few studies to the authors' knowledge have done so for common currency areas among emerging markets. Our assessment relies on a description of the market structure and the volume of capital flows, and on an analysis of price data. Both volume and price data are needed because, on the one hand, capital flows may be high on account of diverging fundamentals that would generate higher differentials in the rates of return, rather than because of financial integration; and on the other hand, price convergence may reflect the importance of global shocks rather than financial integration and therefore need to be complemented by the available information on the structure of markets and volume data.

The GCC countries have pursued economic and financial integration since 1981, although there remain several restrictions in the financial account. ${ }^{3}$ The GCC countries exhibit convergence on many macroeconomic indicators and are on the verge of forming a monetary union. Common shocks are important in the GCC, since the economic structure of these countries are very similar (preponderance of the hydrocarbon sector, reliance on imported labor, peg to the dollar or to a basket including the dollar). Nonetheless, and despite the restrictions in the financial account, the limited available data on financial volume show that cross-border flows have grown in the recent past. The financial systems in the GCC remain however dominated by commercial banks, which limits the importance of crossborder equity flows. With the expansion of stock markets in the recent years, capital flows can nevertheless be expected to increase in the medium term.

Against this background, we assess money market integration with widely-used measures of interest rate convergence. The first measure, beta-convergence, evaluates whether interest rates in countries with relatively high spreads ${ }^{4}$ have a tendency to decrease rapidly, relative to those in countries with low spreads. We find strong evidence of financial integration using beta-convergence and we estimate a half-life of two to five months, significantly shorter than what could be found for the Eastern Caribbean Currency Union (another emerging market country group pegged to the US dollar). The second measure, sigma-convergence, which draws from the growth literature, tests whether the cross-country

\footnotetext{
${ }^{2}$ Member countries of the GCC are: Bahrain, Kuwait, Oman, Qatar, Saudi Arabia, and the United Arab Emirates (U.A.E.).

${ }^{3}$ These include restrictions on residents opening accounts abroad and restrictions on investments in local equity and real estate markets.

${ }^{4}$ The spreads are interest rate differentials with respect to a country of reference-normally the largest economy - for the same class of bond. We used Saudi Arabia as the country of reference for the GCC.
} 
standard deviation of interest rates had a declining trend in the years 1993-2009. We find the trend to be negative suggesting that the cross-sectional variation among interest rates decline notwithstanding a widening in this variance with the emergence of the global financial crisis.

We further explored evidence of financial integration in equity markets by analyzing the prices of cross-listed stocks. An important limitation of studies on stock market comovements is that, by focusing on aggregate stock market data (i.e. indexes), econometricians compare the prices of two assets (or baskets of assets) that have different payoffs. There is no reason to expect that two different assets would have similar prices, unless common shocks drive the two price processes. We avoid this pitfall by using the few individual cross-listed stocks for which data were available, in order to assess the relative magnitude of transaction costs in equity markets. Compared with other financial markets, we find that the arbitrage opportunities remain large and fairly persistent, which suggests that the barriers to movement of capital in the Gulf are still important, although less so than in other emerging markets. The main source of sluggishness in the markets seems to be that days during which the two cross-listed stocks are simultaneously traded are infrequent. This aside, the equity markets are fairly efficient at removing price differentials and seem more integrated within the GCC than with global markets.

The rest of the paper is organized as follows. Section II describes the macroeconomic structure and the GCC financial system, Section III describes the data, Section IV presents the results on interest rate convergence and Section V on cross-listed stocks. Finally we provide concluding remarks in section VI.

\section{GCC FinANCIAL SYSTEM}

\section{A. Macroeconomic and Monetary Environment}

Member countries of the GCC have taken important steps to achieve economic and financial integration over the past two decades. Creation of a common currency area was formally declared a goal soon after the foundation of the GCC in 1981. GCC countries have achieved virtually unrestricted intra-regional mobility of goods, national labor, and capital. Formal barriers to free movement of goods, services, national labor, and capital have been largely eliminated. A GCC single common external tariff (CET) rate of 5 percent was implemented in 2003 and a common market ${ }^{5}$ was established in early 2008, although not yet fully implemented.

\footnotetext{
${ }^{5}$ The Common Market would grant GCC citizens equal treatment in all economic activities, especially movement and residence; work in private and government jobs; pension and social security; engagement in all professions and crafts as well as all economic, investment and service activities; real estate ownership; capital movement; tax treatment; stock ownership and formation of corporations; and education, health and social services. The common market is expected to result in increased production efficiencies and an improved
} 
The GCC countries exhibit convergence on many macroeconomic indicators, which also means that they are subject to many common shocks. The convergence criteria ${ }^{6}$ establish ceilings/floors on: inflation rates, short-term interest rates, foreign exchange reserves, fiscal deficits, ${ }^{7}$ and public debt to gross domestic product (GDP) ratios. The GCC countries have attained significant progress toward economic integration and have achieved the convergence criteria on nearly all fronts. Nonetheless, the financial markets in these countries are in different stages of development. Notwithstanding that, international markets differentiate among GCC countries in assessing risks as evidenced by trends in credit default swaps (CDS) spreads (Figure 1).

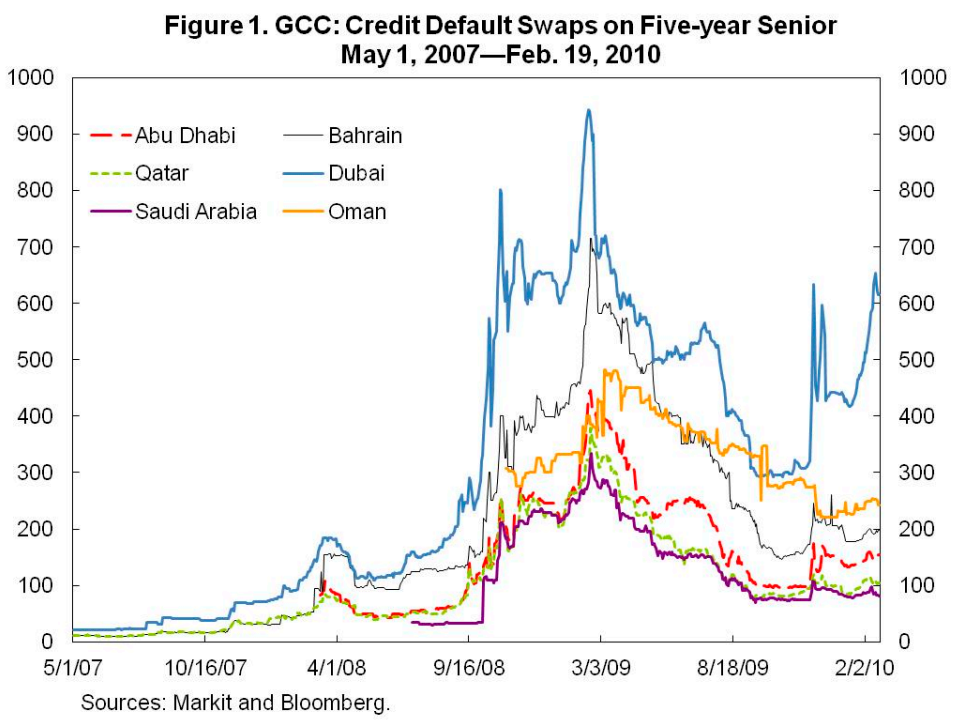

The dollar peg provides the nominal anchor for monetary policy for all GCC with the exception of Kuwait that has a peg to an undisclosed basket. The pegged exchange rate regime has clearly anchored inflationary expectations at low levels and provided certainty about future exchange rates. Within the limits of the peg, the GCC countries operate monetary policy and manage liquidity and credit through interest rates and reserve requirements, loan-to- deposit ratios and other prudential norms. ${ }^{8}$ Despite different monetary policy operations, nominal interest rates have generally tended to converge- - we will

negotiating position in international economic forums. However, full implementation of the common market will require changes to national laws, including those pertaining to limits on company ownership by foreigners.

${ }^{6}$ The convergence criteria that have been agreed and is under discussion, but not yet formally adopted comprise: (i) inflation rate should be no higher than the weighted average of all members plus two percentage points; (ii) interest rate not to exceed the average of the lowest three inter bank rates plus two percentage points; (iii) minimum four months reserves coverage in terms of imports; (v) fiscal deficits not to exceed 3 percent of GDP; and (vi) a maximum public debt ratio of 60 percent of GDP.

${ }^{7}$ The ceiling would be higher if oil prices fall below \$25 per barrel.

${ }^{8}$ The repo rate is the main policy instrument in Saudi Arabia, Qatar and Kuwait; Bahrain operates through a deposit rate; while the U.A.E. uses the benchmark certificates of deposit (CD) rate. In Oman, the cut-off rate in the $\mathrm{CD}$ auction serves as the benchmark rate. 
investigate this in greater depth in the next sections. However, varying domestic factors, including real economic growth, liquidity conditions, the rate of credit growth, and inflationary pressures, have seen interest rates in the GCC countries slightly diverging from U.S. interest rates (Figure 2). ${ }^{9}$

Figure 2. GCC: Nominal Exchange Rates and Interbank Interest Rates
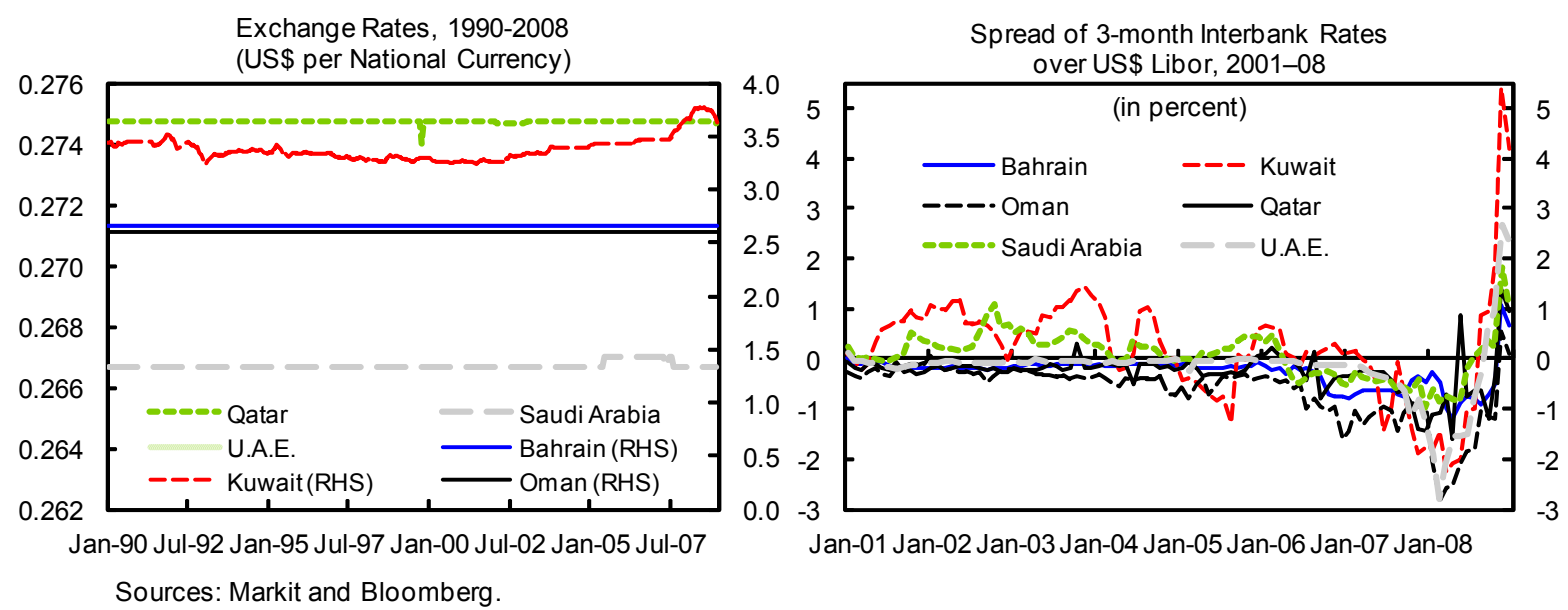

\section{B. Structure of the Financial Sector}

II. Although some governments issue bonds, secondary markets for these instruments are virtually nonexistent in the GCC countries. Equity markets have recently expanded and significantly differ in size between members states, but financial services constitute a major segment of market capitalization in all the countries.

The financial system in the GCC is dominated by commercial banks, both locally incorporated and branches of foreign banks, specialized banks, non-banking financial institutions including leasing and finance companies and investment and brokerage companies, and money exchange house..$^{10}$ The size of the banking system varies across countries, with Saudi Arabia and the U.A.E. accounting for nearly 75 percent of total banks' assets and 70 percent of capital (Table 1 and Figure 3). ${ }^{11}$

\footnotetext{
${ }^{9}$ For instance, some GCC countries did not follow the reduction in U.S. rates during 2007, on considerations of domestic inflation.

${ }^{10}$ The size of operations of investment companies in Kuwait and that of wholesale banks in Bahrain are important.

${ }^{11}$ The six GCC states in the region account for 58 banks in the top 100 Arab banks in 2007, led by the U.A.E. with 18 banks and Saudi Arabia with 11 banks. U.A.E. account for 21 percent and Saudi Arabia for 30 percent of the aggregate Tier 1 Capital. The 11 Saudi banks account for 23 percent of aggregate assets and 38 percent of aggregate profits of the Top 100 making them the most profitable in the region.
} 
Table 1. GCC: Structure of the Banking Sector

\begin{tabular}{lccccc}
\hline & \multicolumn{5}{c}{$\begin{array}{c}\text { Market Share to Total assets } \\
\text { (in percent) }\end{array}$} \\
\cline { 2 - 6 } Country & Total & $\begin{array}{c}\text { Domestic } \\
\text { Banks }\end{array}$ & $\begin{array}{c}\text { Foreign } \\
\text { Banks }\end{array}$ & $\begin{array}{c}\text { Share in total } \\
\text { GCC bank } \\
\text { assets }\end{array}$ \\
\hline Bahrain 1/ & 30 & 45 & 55 & 6 & 304 \\
Kuwait & 17 & 90 & 10 & 13 & 90 \\
Oman & 17 & 90 & 10 & 3 & 68 \\
Qatar & 16 & 90 & 10 & 10 & 110 \\
Saudi Arabia & 17 & 98 & 2 & 32 & 72 \\
U.A.E. & 52 & 78 & 22 & 36 & 151 \\
\hline
\end{tabular}

Sources: Fund staff estimates.

$1 /$ retail banks only. In addition Bahrain has a wholesale banking system with assets of $\$ 450$ billion of which $\$ 50$ billion are domestic assets.

Figure 3. GCC: Banking System Assets and Capital

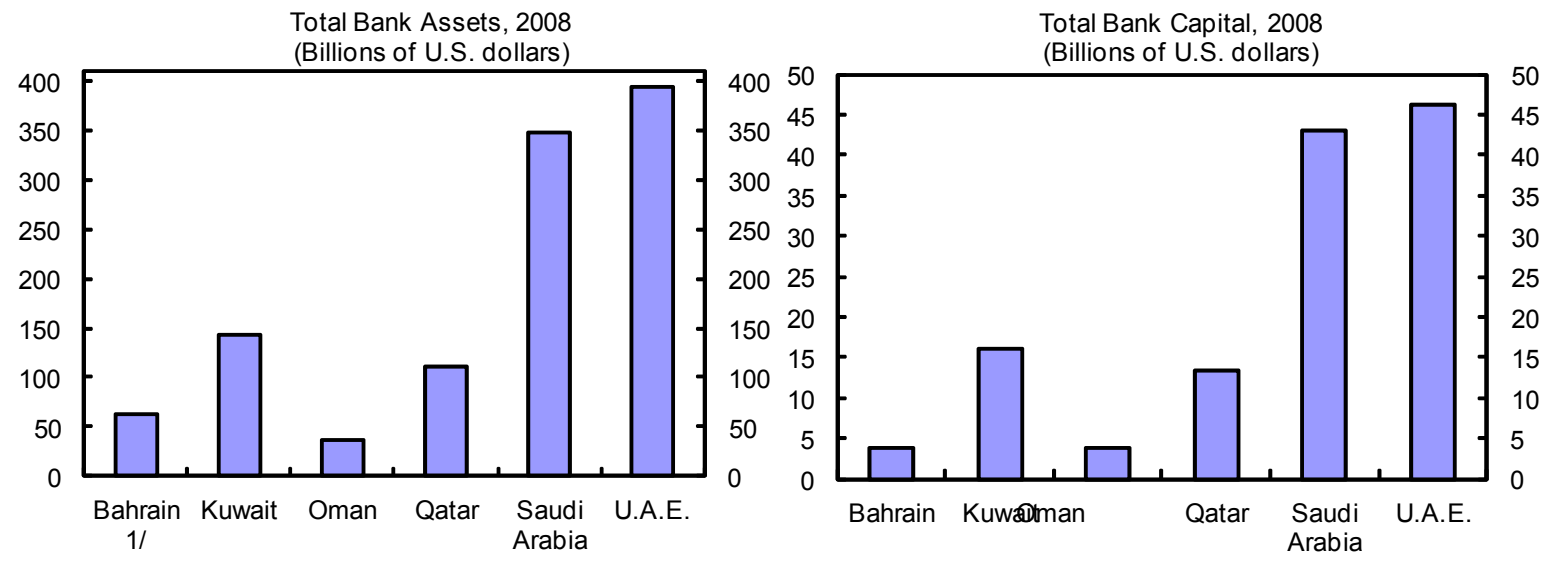

Source: Country authorities; and Fund staff estimates.

$1 /$ includes assets of retail banks only.

Banks in the GCC are well capitalized and bank soundness indicators exhibit stability across countries (see Table 7). ${ }^{12}$ The operations of the banks are domestically oriented, relying mainly on lending and private deposits. Foreign assets and liabilities form a relatively small share of the total size of the balance sheet. Saudi Arabia's banking sector is the most closed - only 8.6 percent of liabilities originate abroad - while Bahrain has the most open banking industry: up to 47 percent of liabilities are foreign (Table 2).

\footnotetext{
${ }^{12}$ Indeed, all GCC countries have sound financial systems, and prudential regulations and supervision of the banking sector are being gradually harmonized. Overall the ratio of non performing loans (NPLs) to total loans remains low by international standards.
} 
Table 2. GCC: Loans, Deposits and Foreign Assets and Liabilities, 2008

GCC Banks: Deposits and Loans (In percent)

\begin{tabular}{|c|c|c|c|c|c|c|}
\hline & Loans to GDP & Deposits to GDP & Loan to Deposit & & $\begin{array}{l}\text { Foreign Assets/ } \\
\text { Total Assets }\end{array}$ & $\begin{array}{c}\text { Foreign Liabilities/ } \\
\text { Total Liabilities }\end{array}$ \\
\hline Bahrain 1/ & 80.9 & 61.1 & 132.4 & Bahrain 1/ & 53.4 & 47.0 \\
\hline Kuwait & 56.3 & 58.3 & 96.5 & Kuwait & 22.4 & 14.5 \\
\hline Oman & 42.8 & 30.9 & 138.8 & Oman & 17.1 & 15.0 \\
\hline Qatar & 47.0 & 54.4 & 86.4 & Qatar & 24.7 & 22.2 \\
\hline Saudi Arabia & 40.7 & 46.9 & 86.9 & Saudi Arabia & 11.8 & 8.6 \\
\hline U.A.E. & 76.2 & 90.8 & 83.9 & U.A.E. & 15.4 & 22.6 \\
\hline
\end{tabular}

GCC Banks: Foreign Assets and Liabilities (In percent)

Source: Fund staff estimates.

1/ Retail banks only.

The capital accounts of these countries are open, but some controls exist. All GCC countries operate an open regime for foreign exchange accounts for both residents and non residents. In the GCC, residents can open foreign exchange accounts domestically and abroad and resident accounts in domestic currency are convertible in foreign currency. Similarly, non residents are permitted to open domestic currency and foreign currency accounts.

Restrictions however remain in a number of important areas. There are restrictions on the purchase of shares in the local markets by non residents, though GCC nationals get a more favored treatment. There are also many additional controls on inward foreign direct investment (FDI). A number of rules and regulations with regard to reserve requirements, open forex positions, payment of dividend and remittance of profits, controls regarding lending to non residents and restrictions on foreign borrowing by individual banks exist (see Table 3 for more details). Although some restrictions are relaxed within the GCC, many apply without discriminating the source of the inflows, thereby hampering regional as well as global integration.

\section{Available Volume Data}

Regional capital flow data is limited. However, information on the volume of capital flows is a useful complement to the analysis of the price data presented later in this paper. Generally, data on capital flows can be obtained from (i) United Nations Conference on Trade and Development (UNCTAD) FDI data; (ii) data on mergers and acquisitions; and (iii) the Coordinated Portfolio Investment Survey (CPIS) conducted by the IMF. The UNCTAD FDI bilateral (i.e. by source and destination country) data was not available for the GCC, but we did find data on regional mergers and acquisitions in the financial sector. The CPIS data provided also some useful information. 
Table 3. GCC: Restrictions on Resident and Nonresident Deposit Accounts

\begin{tabular}{|c|c|c|c|c|c|c|}
\hline & Bahrain & Kuwait & Oman 1/ & Qatar 1/ & Saudi & U.A.E. \\
\hline \multicolumn{7}{|l|}{ Resident Accounts } \\
\hline Foreign exchange accounts permitted & Yes & Yes & Yes & Yes & Yes & Yes \\
\hline Held domestically & Yes & Yes & Yes & Yes & Yes & Yes \\
\hline Held abroad & Yes & Yes & Yes & Yes & Yes & Yes \\
\hline Accounts in domestic currency held abroad & No & n.a & No & n.a. & No & Yes 2/ \\
\hline $\begin{array}{l}\text { Accounts in domestic currency } \\
\text { convertible into foreign currency }\end{array}$ & Yes & Yes & Yes & Yes & Yes & Yes \\
\hline \multicolumn{7}{|l|}{ Nonresident accounts } \\
\hline Foreign exchange accounts permitted & Yes & Yes & Yes & Yes & Yes & Yes 3/ \\
\hline Domestic currency accounts & Yes & Yes & Yes & Yes & Yes & Yes \\
\hline Convertible into foreign currency & Yes & Yes & Yes & Yes & Yes & Yes \\
\hline \multicolumn{7}{|c|}{ Source: IMF Exchange Rate Arrangements and Restrictions, 2007.} \\
\hline \multicolumn{7}{|c|}{$\begin{array}{l}3 / \text { These accounts may be opened by banks and trade, financial and industrial companies incorporated outside the U.A.E } \\
\text { that have no local branches; by branches of local institutions in foreign countries; and by embassies and diplomatic } \\
\text { agencies. These accounts may also be opened by U.A.E. citizens working abroad and by nonresident foreigners } \\
\text { working in the U.A.E. }\end{array}$} \\
\hline
\end{tabular}

Mergers and acquisitions in the GCC were dynamic as the banking system was responding to various market developments in the financial sector and the opening up of the telecommunication sector (Table 4). Kuwait, Saudi Arabia and the U.A.E. were the most active in mergers and acquisitions within the GCC region.

Table 4. GCC: Mergers and Acquisitions

(In millions of U.S. Dollars)

\begin{tabular}{lrrrrrrr}
\hline $\begin{array}{c}\text { Acquirorl } \\
\text { Target Country }\end{array}$ & Bahrain & Kuwait & Oman & Qatar & Saudi Arabia & U.A.E. & $\begin{array}{r}\text { Inter GCC } \\
\text { Investments }\end{array}$ \\
\hline Bahrain 1/ & & 395.8 & 155.5 & 200.8 & 0.0 & 0.1 & 752.2 \\
Kuwait & 422.0 & & 18.3 & 21.8 & $12,536.6$ & 86.7 & $13,085.4$ \\
Oman & 0.0 & 0.0 & & 199.6 & 0.0 & 0.0 & 199.6 \\
Qatar & 5.8 & $4,249.2$ & 322.7 & & 0.0 & 820.7 & $5,398.5$ \\
Saudi Arabia & 0.0 & 957.2 & 451.3 & 0.0 & & $3,364.2$ & $4,772.8$ \\
U.A.E. & $1,141.9$ & 118.4 & 427.6 & 0.0 & 485.9 & & $2,173.8$ \\
Total GCC & $1,569.8$ & $5,720.7$ & $1,375.5$ & 422.2 & $13,022.5$ & $4,271.8$ & $26,382.4$ \\
& & & & & & & \\
\hline
\end{tabular}

Source: Dealogic Analytics.

Despite the common shocks that affect the GCC, the intra-regional demand for GCC securities has been increasing, as suggested by the CPIS data for Kuwait and Bahrain (the only countries for which data was available, see Table 5). Bahrain and Kuwait are the countries with the closest ties to the region, so these numbers probably overstate the intraregional demand for asset. The trend is however interesting to note. The share of GCC equities in Bahrain's total portfolio investments rose from 5 percent to 30 percent between 2004 and 2007. For Kuwait, the share of GCC equities rose from 37 to 58 percent. Bahrain holdings of GCC long-term debt rose from 8 to 15 percent of its total holdings (Table 6). 
Table 5. Portfolio Investment Asset in GCC Partner - Equity (Stock, in shares of total reported asset)

\begin{tabular}{lrrrrr}
\hline & 2003 & 2004 & 2005 & 2006 & 2007 \\
\hline Bahrain & n.a. & 0.05 & 0.11 & 0.22 & 0.3 \\
Kuwait & 0.37 & 0.40 & 0.48 & 0.54 & 0.58 \\
\hline
\end{tabular}

Source: Fund staff estimates.

Table 6. Portfolio Investment Asset in GCC Partner Long-Term Debt Securities

(Stock, in shares of total reported asset)

\begin{tabular}{lccccc}
\hline & 2003 & 2004 & 2005 & 2006 & 2007 \\
& & & & & \\
\hline Bahrain & n.a. & 0.08 & 0.07 & 0.15 & 0.15 \\
Kuwait & n.a. & n.a. & n.a. & 0.19 & 0.15 \\
& & & & & \\
\hline
\end{tabular}

Source: Fund staff estimates.

These numbers may overstate the trend increase as the size and depth of the stock markets in the GCC have expanded over time (see Figure 4). The importance of financial services as a major share of the market capitalization in all the GCC countries (ranging from 32 percent in Saudi Arabia to 80 percent for Bahrain) may also distort the picture.

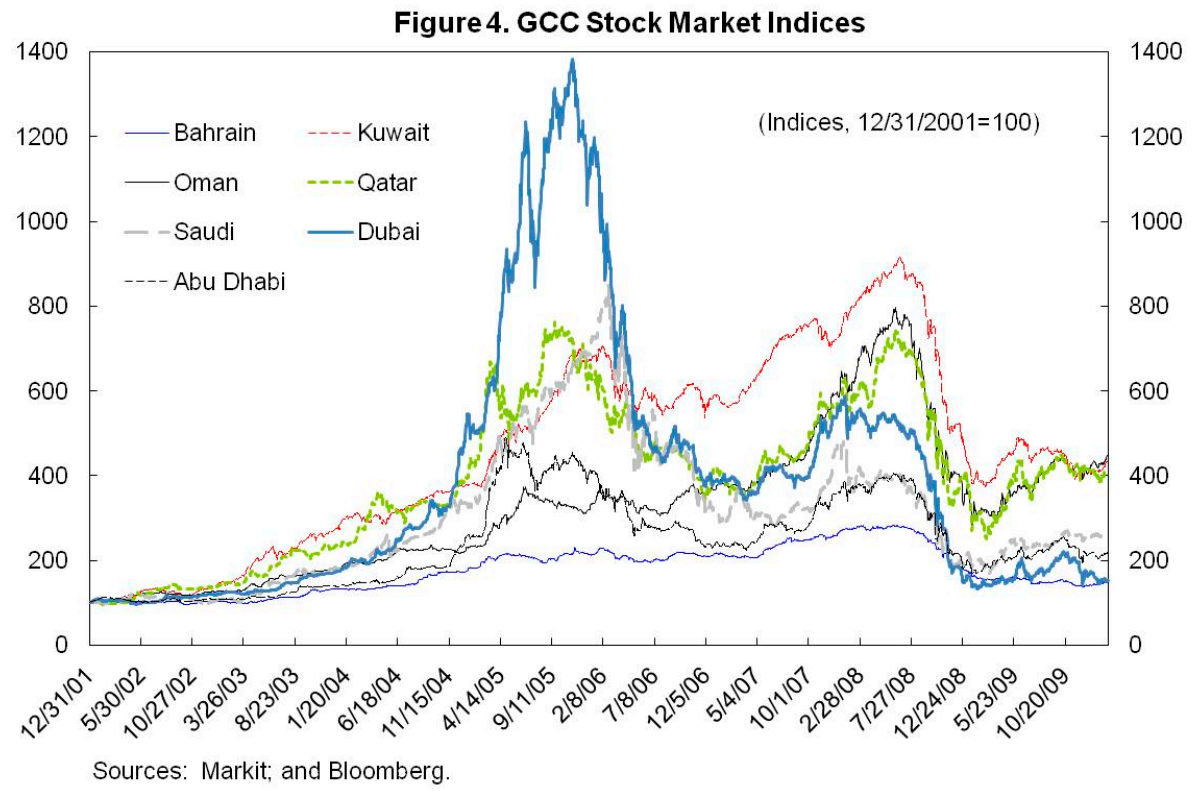




\section{Price Data: Interest Rate And Cross-Listings}

We now investigate the dynamics of price data through an analysis of interest rate convergence and cross-listing pricing. Using both data sets we estimate how fast price/yield differentials across countries are arbitraged away. The peg to the U.S. dollar implies that, by design, the GCC interbank rates should not diverge. However, rates may diverge for several reasons, including capital flows that give rise to differences in the assessment of country and currency risks, and different liquidity, monetary conditions, and fiscal stance.

For interest rates, we use three-month interbank rates in local currency for the six GCC countries, sourced from the Saudi Arabian Monetary Authority (SAMA) monthly statistical bulletin. Monthly data spanning 1993-2009 were used to estimate both beta and sigma-convergence (see Figure 6). In order to compare our results to that of another emerging market group pegged to the US dollar, we obtained monthly interest rate data for the Eastern Caribbean Currency Union (ECCU), for treasury bills, and lending and deposit rates from the IMF's International Financial Statistics. Saudi Arabia and St. Kitts and Nevis interest rates were used as benchmark rates in calculating the spreads. We also use daily data from cross-listed stocks in the GCC. The number of cross-listings is by itself a measure of financial integration since it reflects firms' ability to obtain financing regionally.

Figure 5. GCC Interbank Rates

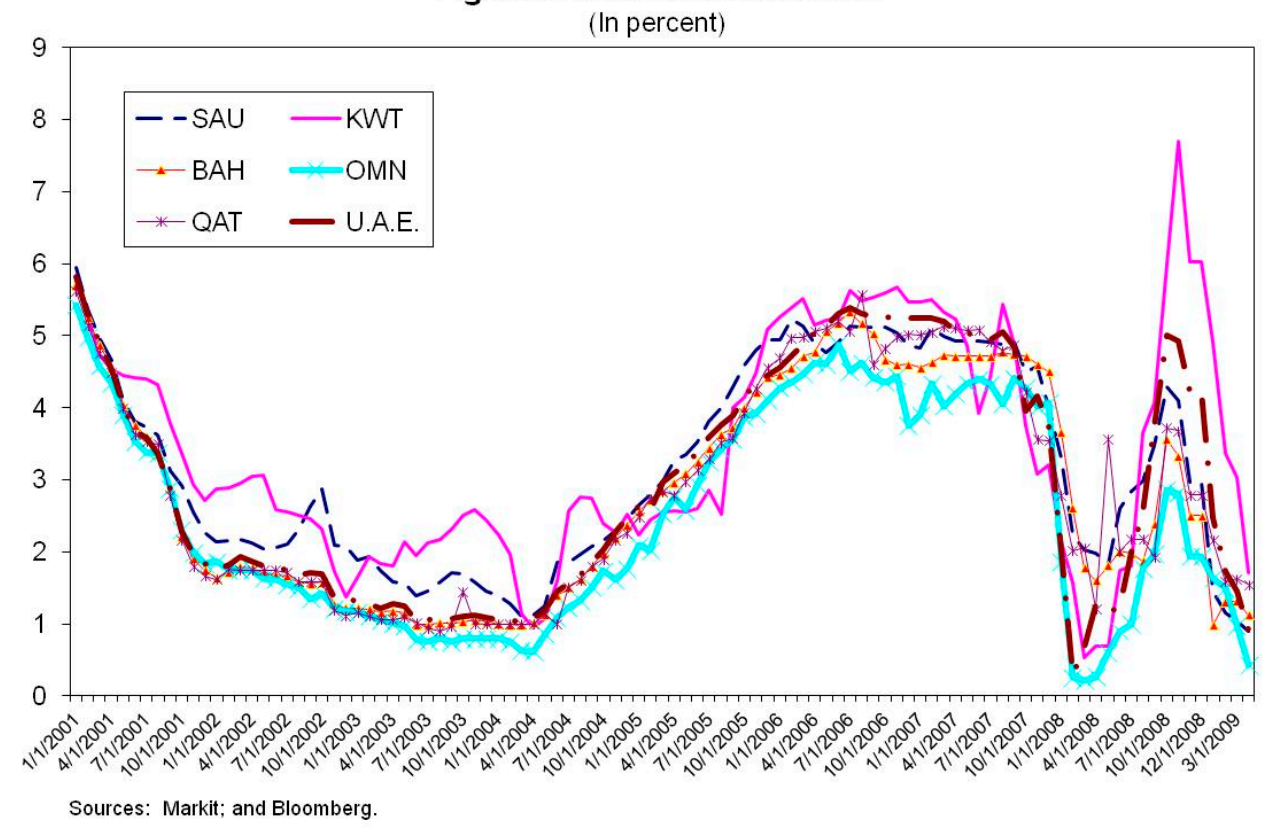

Table 13 reports some cross-listings found for the major emerging markets and Organization for Economic Cooperation and Development (OECD) regions. This data is rudimentary as it reflects the bias of DataStream towards developed markets as well as our 
own focus on selected regional markets..$^{13}$ Nonetheless, some meaningful patterns emerge that put into perspective the few cross-listings found for the GCC. Hong Kong, the United States, the United Kingdom and Germany are important financial hubs that attract hundreds of cross-listings.

In comparison, only a few stocks are listed in the less developed markets such as the GCC and the Caribbean region (CARICOM). We identified around 15 assets cross-listed in the GCC, most of them between Bahrain and Kuwait, and were able to collect usable data for 6 of them. In order to give a cross-regional perspective to our measure of regional financial integration, we present our main results together with summary statistics obtained for Latin America, the Caribbean, Hong-Kong, Singapore and Europe and analyzed in an earlier study (Espinoza and Kwon, 2009). We also identified one equity (Gulf Finance House) that had usable data of cross-listings in four markets, including two in the Gulf and two in Europe. This equity will allow us to compare arbitrage opportunities within and across regions and speculate on the causes of price differentials. The list of equities analyzed in the paper is presented in Table 14.

In order to keep only meaningful price information, all data from days in which trading volumes were not positive for both markets were removed. The final series are therefore shorter than the original ones because only simultaneous trading days data was kept. Since liquidity is limited in many of these markets, the 'period' between two simultaneous trading days (what is labeled the 'trading period') can be long and exceed a week of working days.

\section{INTEREST RATES CONVERGENCE}

\section{A. Beta Convergence and Sigma Convergence}

The assessment of financial integration using bond markets has normally relied on two measures of interest rate convergence. The first measure of financial integration is beta $(\beta)$-convergence that draws on the empirical growth literature and evaluates whether GCC countries interest rates have a tendency to converge towards the baseline rate. This measure involves using panel data to regress:

$$
\Delta S_{i t}=\alpha_{i}+\beta S_{i t-1}+\sum_{l=1}^{L} \gamma_{l} \Delta S_{i t-l}+\varepsilon_{t}
$$

\footnotetext{
${ }^{13}$ DataStream was used nonetheless since its search engine is powerful for the purpose of identifying crosslistings. Cross-listing from country A to country B was defined in the search engine by the fact that a stock from a company from country $\mathrm{A}$ is traded in the currency of country B. There are some instances where this definition is restrictive: for instance, a dozen of Euro Area companies are listed in the UK in U.S. dollars. Similarly, around 20 British companies are listed in the UK in euro. Since these situation mostly reflect global financial integration rather than regional integration, these instances were not included in table 2.
} 
where $\mathrm{S}_{\text {it }}$ represents the yield spread on a 3-month interbank interest rate in country $i$ at time $t$, relative to the Saudi Arabian rate as a benchmark.

The second measure employs sigma $(\sigma)$-convergence which occurs if the crosssectional distribution of a variable (typically income per capita in the growth literature, and interest rates in the financial integration literature) decreases over time. ${ }^{14}$ According to the sigma-convergence measure, the degree of financial integration increases when the crosssectional standard deviation of a variable trends downwards. If the cross-sectional distribution collapses to a single point, and the standard deviation converges to zero, full integration is achieved (Adam et al., 2002). The measure of cross-sectional dispersion $\left(\sigma_{t}\right)$ in interbank rates for a country $R_{i}$ at each point in time is calculated as follows:

$$
\sigma_{t}=\left[\frac{1}{n-1} \sum\left(R_{i t}-R_{t}^{-}\right)^{2}\right]^{1 / 2}
$$

The speed at which the cross-sectional dispersion decreases over time could be derived by regressing $\sigma_{t}$ on a time trend. An important distinction between the two measures is that $\beta$-convergence does not imply $\sigma$-convergence because mean reversion does not imply that the cross sectional variance decreases over time (Quah, 1993; and Adam et al., 2002). We will interpret the first measure as a measure of integration, whereas the second measure captures the trend in integration, i.e. if the standard deviation declines over time, integration have gone further.

\section{B. Results}

The first measure of financial integration, beta-convergence (see results in Tables 9), suggested convergence of spreads among GCC countries during the period under study. The Saudi Arabian 3-month interbank rate was used as the benchmark. The estimated coefficient on the lagged spread was negative and significant and was robust to the method of estimation. The Breusch-Pagan tests suggests that one needs to take into account individual effects (i.e. the variance of individual effects is non-zero) while the Hausman specification tests indicates a fixed effects model best characterizes the data generating process for the GCC.

The half-life for deviations from the benchmark ranged between $3 \frac{1}{2}$ to $5 \frac{1}{2}$ months suggesting a fast convergence relative to our control group, the ECCU—another emerging market group with a peg to the dollar. ${ }^{15}$ GCC panel half lives compared favorably with the countries of the ECCU panel where the half life for treasury bills, lending and deposit rates

\footnotetext{
${ }^{14}$ In the growth literature, $(\sigma)$ - convergence occurs if the cross-sectional distribution of a variable e.g. income per capita decreases over time. This measure is applied to the degree of financial integration by examining the cross-sectional dispersion of three-month interbank lending rates.

${ }^{15}$ The half life was calculated as $\ln (0.5) / \ln (1+\beta)$.
} 
ranged between 4-14 months (Tables 10-12). ${ }^{16}$ According to individual regressions (as opposed to panel regressions), the rate at which individual country spreads converged ranged from two months for Saudi Arabia-Qatar spreads to about five months for Saudi ArabiaKuwait spreads, but this heterogeneity in coefficients was within the range provided by the panel models and therefore did not seem to be detrimental to panel estimation.

GCC spreads tended to converge faster since 2000 with half lives ranging between two to four months relative to earlier periods (Table 8). This was based on estimates in Table 8 column 5 that illustrates that the coefficient on the spread with a dummy for periods greater than 2000 was significantly different from zero (negative) which implies that the speed of convergence after 2000 is significantly greater than that of earlier periods. The half-life measure indicates that profit-seeking flows would nonetheless take 2 to 5 months to clear half of the arbitrage opportunities provided by interest rate differentials despite the peg to the dollar. Given half lives of GCC interest rate differentials take longer than two months despite open capital accounts, there is a case for developing money market instruments that permit a more effective management of structural liquidity.

The longer half lives in the ECCU relative to the GCC countries could reflect the restrictions on the capital accounts, a lack of competition in the banking sector, and very illiquid bond markets (see Kwon et al, 2008, and Chai, 2006, for studies on financial integration and the banking system in the Caribbean).

The results for sigma convergence suggest that the convergence in the cross sectional variation was achieved between 1993 and 2009 (see Table 7). ${ }^{17}$ This was based on negative and significant coefficient on the time trend. However, post 2000, convergence slowed as the cross-sectional variation increased with the onset of the global crisis toward the end of the period under study (Table 8).

Owing to the dollar peg, interest rate convergence seems therefore to be relatively quick in the GCC, although it is slowed by differences in capital movements, in assessment of country risk, currency risk, fiscal policy stance, and monetary policy responses to FED rate decisions (for example in 2008 both Qatar and U.A.E. did not adjust their policy rates to all of the cut in the FED funds rate). Interest rates would have converged after the Gulf War, and come further closer since 2000, although spreads widened temporarily during the worst months of the current crisis.

\footnotetext{
${ }^{16}$ The T-bill rate half life ranged for 5-10 months, deposit rates 10-14 months, and lending rates 4-10 months.

${ }^{17}$ For comparison, we tested for sigma convergence in the ECCU and find that there was convergence for both the lending and deposit rates, but not for treasury bills (Figure 6).
} 


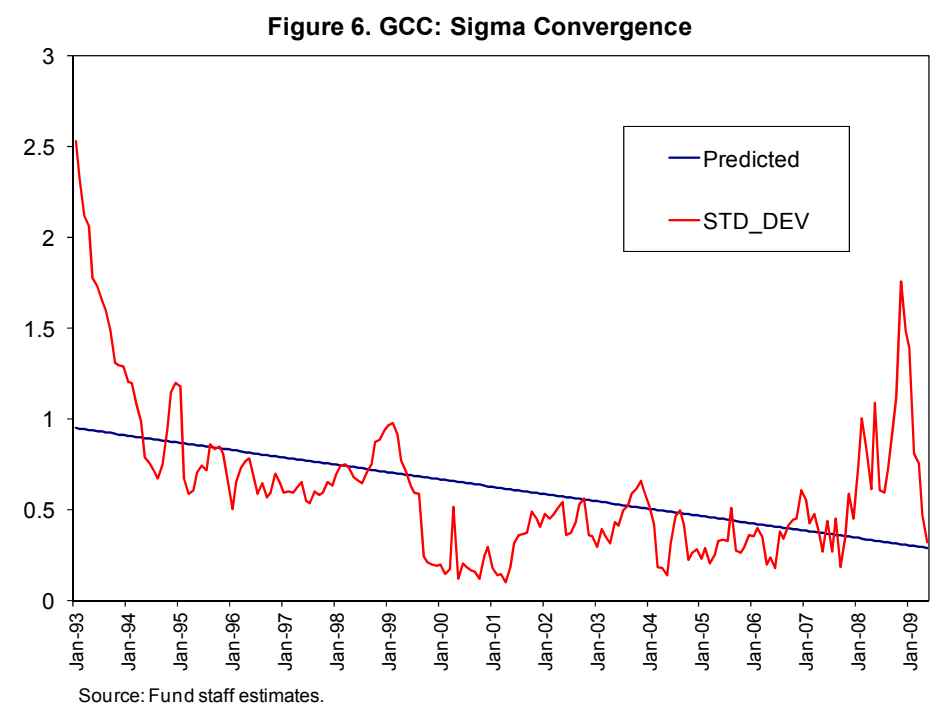

V. Cross-Listed Stocks

\section{A. Theory}

We estimate the size of 'arbitrage opportunities' in the GCC using cross-listed stock price data, i.e. price data of one equity listed in two different markets, and for which the noarbitrage condition is expected to hold. The no-arbitrage condition is a property satisfied by any equilibrium in absence of taxes, market segmentation or other market imperfections. In the presence of a transaction $\cos t \tau$ the arbitrage condition fails, but one can characterize the relationship between the price $\mathrm{P}_{1}$ and $\mathrm{P}_{2}$ of the two equivalent assets thanks to the following inequality (Tsomocos, 2003):

$$
1 /(1+\tau) P_{2} \leq P_{1} \leq(1+\tau) P_{2}
$$

Hence, although there is no strict equality of prices, the arbitrage opportunity (or premium) $\mathrm{P}_{1} / \mathrm{P}_{2}-1$ is expected to remain confined to the interval:

$$
1 /(1+\tau)-1 \approx-\tau \leq P_{1} / P_{2}-1 \leq \tau
$$

The size of the arbitrage opportunity is therefore a measure of the transaction cost that affects the trading of the two equivalent assets. We investigate the size and dynamics of this price differential in the following sections, with a primary focus on GCC assets.

\section{B. Method}

Cross-listed stocks have been used in many studies of pricing behavior but the paper from which we borrow is that of Levy Yeyati et al. (2006), who estimate Auto-Regressive (AR) models of the cross-market premium, i.e. the premium between the prices of cross-listings. 
The authors chose stocks cross-listed in the United States and in several emerging markets, ${ }^{18}$ and estimated that the cross-market premium is low, at 0.16 percent. The average (absolute value) cross-market premium is a simple measure of integration that helps us diagnosis market inefficiencies.

Levy-Yeyati et al. (2006) find that the arbitrage opportunities are short-lived (most often less than one day)., The speed at which the price differential is closed captures the persistence of arbitrage opportunities and is likely to be related to the volume of flows attracted by the arbitrage opportunity. This speed of price convergence, which we estimate using AR models with GARCH, constitutes our second measure of financial integration.

According to Equation 4 there is an interval, the 'neutral band', in which price differences are too low to be arbitraged away. As a result, non-linearities in the adjustment process are prevalent and we estimate a Threshold AR model to take this non-linearity into account (see Tong, 1978 ; Obstfeld and Taylor, 1997, for an application to the Law of One Price for goods, and Levy-Yeyati et al., 2006). The size of the neutral band in a Threshold model is our third estimate of the importance of transaction costs.

The stock prices of the different equities we covered are plotted in Figures 7 and 8, after conversion in the same currency. Cross-listed prices evolve very close to each other, although small arbitrage opportunities (in blue, at the bottom of each chart) exist.

\section{Results}

We show in Table 14 the average size of the arbitrage opportunities for the six GCC equities, together with that obtained in an earlier study on other regions. We find that, at around 2 to 4 percent, the mean arbitrage opportunity is smaller in the GCC than in the markets of Hong-Kong and Singapore and in the Caribbean. The GCC average arbitrage opportunity is however larger than the price differential obtained for the company Petrobras listed in Argentina and Brazil. The GCC markets are also less efficient in removing arbitrage opportunities than the western developed markets, for which arbitrage opportunities hover around 1 percent. However, the GCC equity for which we found cross-listings in both London and Frankfurt (Gulf Finance House, GFH, Figure 7) also exhibits significant arbitrage opportunities even between developed markets, ${ }^{19}$ which suggests there are also issues with the pricing and treatment of information for Gulf equities outside of the GCC markets.

\footnotetext{
${ }^{18}$ After excluding stocks they consider to be too illiquid, they found 76 firms from Argentina, Brazil, Chile, Indonesia, South Korea, Mexico, Russia, South Africa and Venezuela that were listed both domestically and in the United States.

${ }^{19}$ Arguably, the price differentials widened during the crisis: indeed, the price differential between London and Frankfurt for GFH was only 2 percent on average before the fall of Lehman, and reached 5.5 percent afterwards. Nevertheless, 2 percent is a sizeable premium, comparable to that prevalent between GCC markets and higher than that of advanced markets stocks.
} 
Figure 7. Selected Cross-Listed Stocks in the GCC
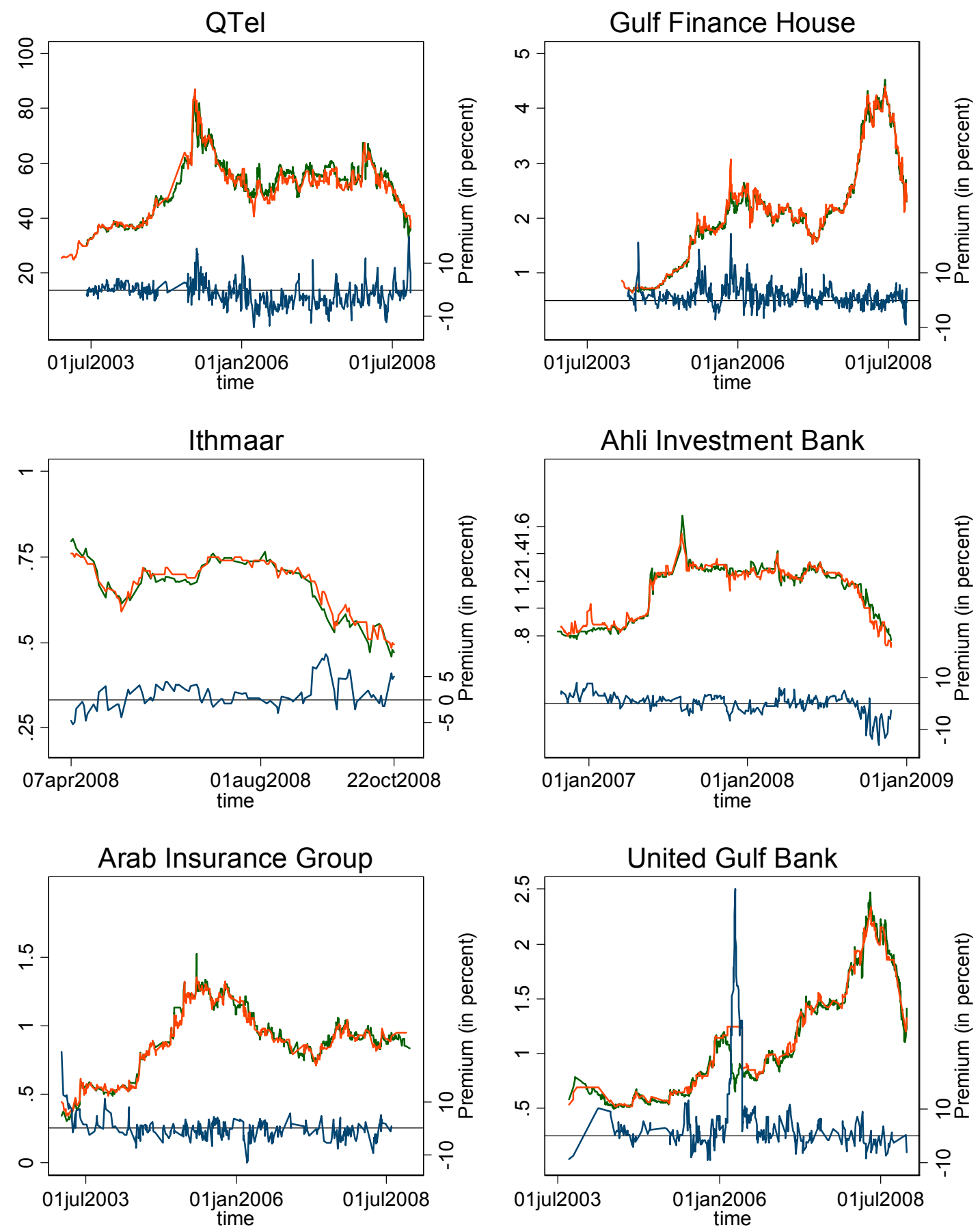

Sources: Bloomberg and authors' calculations. 
Figure 8. Gulf Finance House Cross-Listings
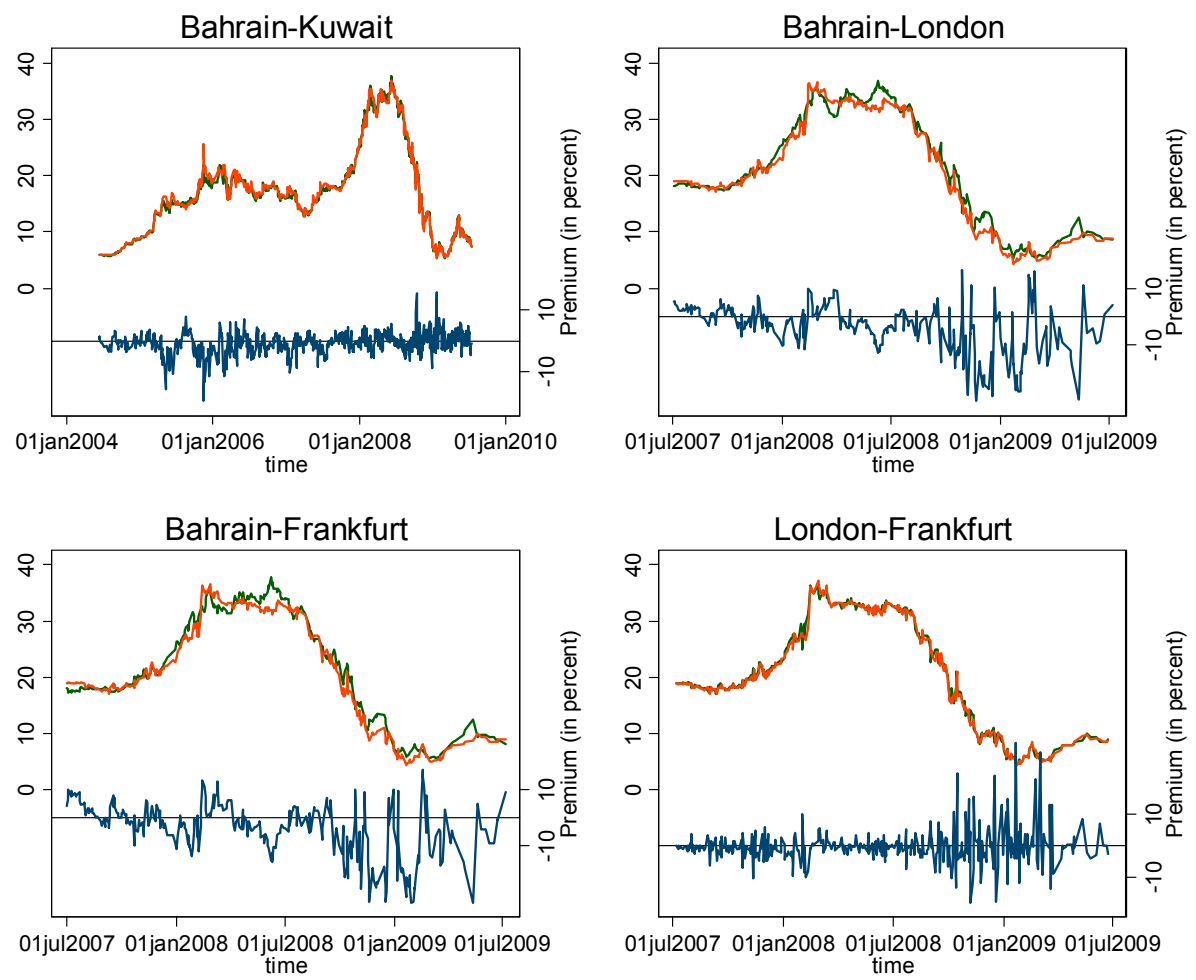

Source: Bloomberg; and authors' calculations.

Some potential explanations to these fairly large arbitrage opportunities are:

- $\quad$ lagging information on events originated in the other markets;

- $\quad$ market illiquidity (e.g. if the price is affected by a large trading in one of the market);

- $\quad$ inefficiency in the functioning of the market (number of opening days, sluggishness in transferring the order, etc).

- actual transaction costs (costs of making an order, exchange restrictions - although these are very limited in the recent years); and

- $\quad$ government intervention (which reduces the float and hence market liquidity).

We further investigate the dynamics of the arbitrage opportunities by looking at two AR models. The half-lives of the price differentials presented in number of trading days (Column B in Table 15) are fairly short, around two days, and at par or even shorter than for more advanced markets (such as Argentina/Brazil and Hong-Kong/Singapore), although the half-lives are longer than that for the developed markets (France/Germany is our advanced markets control group). Hence, the markets are good at seizing arbitrage opportunities when 
trading takes place. It is interesting to note that the within-GCC arbitrage opportunities are also smaller and vanish more quickly than the price differentials between a GCC market and 'world markets' (see in Figure 8 and Table 15 the GFH trading between Bahrain and the UK or Germany). This would suggest that 'regional' integration in the Gulf is at least at par with GCC 'global' integration. However, half-lives in week days (Column C in Table 15) are long, around 6-7 days, which shows that arbitrage opportunities are actually persistent because trading days are infrequent — although less so than in the less developed markets of the Caribbean and Hong-Kong/Singapore. Infrequent trading (that is partly due to the opening days and partly due to illiquidity) is therefore a source of price differentials in the GCC and a significant barrier to integration. The dynamics of the GFH premium between London and Frankfurt does not suffer from this obstacle: the equity is traded frequently (every 1.3 week day on average) and with a high convergence speed (the half-life is lower than a day). Arbitrage opportunities between the Gulf and the advanced markets are on the other hand very large (exceeding 6 percent) and as persistent as the GCC price differentials, which would suggest that processing information and trading between the Gulf and Europe is difficult.

We finally look at the neutral band $c$ using the Threshold AR model (see Table 16, Column A). The GCC markets fare well on average according to this measure (the neutral band would be small). In particular, for three equities the value of the threshold is very low compared to the average premium, which suggests that the arbitrage opportunities quickly become large enough to attract capital. Hence, our results suggest again that the presence of arbitrage opportunities is due to illiquidity, rather than to the size of transaction costs.

We conclude that, although the GCC equity markets are more integrated than many emerging economies markets, and although GCC integration seems more advanced than integration with global markets, there remain issues with the functioning and liquidity, and processing of information, which make the arbitrage opportunities larger and more persistent than within advanced markets.

\section{Conclusion}

We analyzed the extent of regional financial integration in the GCC using capital flow data, interest rates, and equity prices. Although information on volumes is limited, the available data suggests that there is some regional integration-Bahrain and Kuwait, especially, direct a large share of their investments towards the GCC. Integration would have gone further in the recent years, although our assessment on volume data may be biased by the increasing importance of the equity markets and some valuation effects. Looking at price data, we find evidence of financial integration using the beta convergence measure, a result mostly driven by a common peg to the U.S. dollar. We found that it takes 2 to 5 months to clear interest rate differentials in the GCC, and that this was faster than within the ECCU. Within-GCC convergence was also marginally faster than beta-convergence with dollar rates. 
Interest rate integration using sigma-convergence seems to have improved mostly between 1993 and 2000, with little additional progress afterwards.

Using price differentials of stocks cross-listed in two countries, we found that the average arbitrage opportunity in the GCC was around 3 percent and that it was arbitraged away within a couple of trading days. Pricing of cross-listings within the GCC seemed to more efficient than pricing between the GCC and Europe, suggesting that regional integration is at least at par with global integration. However, days during which the crosslisted stocks are traded in both markets are infrequent in the GCC, which makes the clearing of price differentials much slower when counted in week days. The relatively open capital accounts in the GCC in part explain the relatively fast convergence, despite the existence of some restrictions and illiquidity of markets. 


\section{REFERENCES}

Adam, K., Jappelli T., Menichini A. M., Padula M., and M. Pagano (2002), Analyse, Compare, and Apply Alternative Indicators and Monitoring Methodologies to Measure the Evolution of Capital Market Integration in the European Union, Report to the European Commission.

Baele, L., A. Ferrando, P. Hördahl, E. Krylova and C. Monnet (2004), Measuring Financial Integration in the Euro Area, Occasional No. Paper 14

Chai, J., 2006, “The Eastern Caribbean Currency Union Banking System in a Time of Fiscal Challenge," in R. Sahay, D.O. Robinson and P. Cashin (editors), The Caribbean: From Vulnerability to Sustained Growth, Washington DC: International Monetary Fund, pp. 143-180.

ECB (2005), Indicators of financial integration in the Euro Area, European Central Bank

Edison H. and C. Reinhart (2001), Stopping hot money, Journal of Development Economics, Vol 66, pp. 533-553.

Espinoza R. and G. Kwon (2009), Regional Financial Integration in the Caribbean: Evidence from Financial and Macroeconomic Data, IMF Working Paper, WP 09/139.

International Monetary Fund (2007), Exchange Rate Arrangements and Restrictions, washington DC.

Kwon, G., S. Panth, J. Chai, A. Gerson, G.M. Casselle and R. Espinoza, 2008, "Financial Integration in the Caribbean," in A. Bauer, P. Cashin and S. Panth (editors), The Caribbean: Enhancing Economic Integration, IMF Western Hemisphere Department, Washington DC: International Monetary Fund, pp. 3-43.

Levy Yeyati E., S.L. Schmukler and N. Van Horen (2006), International Financial Integration through the Law of One Price, World Bank Working Paper WPS2897

Obstfeld M. and A. Taylor (1997), Nonlinear Aspects of Goods-Market Arbitrage and Adjustment: Hechkscher's Commodity Points Revisited, Journal of the Japanese and International Economies, Vol 11. pp 441-479.

Quah, Danny (1993), “Galton's Fallacy and Tests of the Convergence Hypothesis”, Sandinavian Journal of Economics, 95 (4), 427-43. 
Tong, H. (1978), On a Threshold Model, in C.H. Chen (ed.) Pattern Recognition and Signal Processing, Amsterdam: Sijthoff and Noordhoff

Tsomocos D. (2003), Equilibrium analysis, banking and financial instability, Journal of Mathematical Economics, Vol. 39(5-6), pp. 619-655. 
Table 7. Prudential Measures, Latest Available Data

\begin{tabular}{|c|c|c|c|c|c|c|}
\hline & Bahrain 1/ & Kuwait 2/ & Oman & Qatar 2/ & Saudi Arabia 3/ & U.A.E. 4/ \\
\hline Nonperforming Loans (percent) & 3.0 & 3.1 & 3.2 & 1.0 & 2.1 & 2.5 \\
\hline Capital Adequacy & 24.0 & 16.0 & 15.9 & 17.0 & 20.6 & 13.3 \\
\hline Provisioning Rate & & 84.7 & 107.6 & 91.0 & 142.9 & 101.5 \\
\hline Return on Assets & & 3.2 & 2.1 & 2.4 & 2.8 & 2.3 \\
\hline Return on Equity & 12.7 & 27.8 & 14.7 & 21.7 & 30.5 & 21.1 \\
\hline
\end{tabular}

Sources: Global Financial Stability Report (GFSR); National Authorities.

1/ End-2008 for Non-Performing Loans and Capital Adequacy. End-2007 for Return on Equity.

2/ End-September 2008.

3/ End-2006 for Return on Equity, otherwise end-2007.

4/ End-June 2008. 
Table 8. GCC: Tests of Beta Convergence

\begin{tabular}{|c|c|c|c|c|c|}
\hline & (1) & (2) & (3) & (4) & (5) \\
\hline Varriables & OLS & Fixed Effects & $\begin{array}{l}\text { Random } \\
\text { Effects }\end{array}$ & GMM & $\begin{array}{l}\text { Fixed } \\
\text { Effects }\end{array}$ \\
\hline \multirow[t]{2}{*}{ Spread $_{\mathrm{t}-1}$} & $-0.119^{* * *}$ & $-0.174^{\star * *}$ & $-0.119^{* * *}$ & $-0.119^{\star * *}$ & $-0.146^{* * *}$ \\
\hline & [0.0148] & [0.0182] & [0.0148] & [0.021] & [0.0199] \\
\hline \multirow[t]{2}{*}{ Spread $_{\mathrm{t}-1^{*}}$ DUM2000 } & & & & & $-0.0951^{\star * *}$ \\
\hline & & & & & {$[0.0284]$} \\
\hline \multirow[t]{2}{*}{$\Delta$ Spread $_{\mathrm{t}-1}$} & 0.0207 & 0.05 & 0.0207 & 0.021 & $0.0710^{\star *}$ \\
\hline & [0.0321] & [0.0323] & {$[0.0321]$} & {$[0.067]$} & [0.0327] \\
\hline \multirow[t]{2}{*}{$\Delta$ Spread $_{\mathrm{t}-2}$} & $0.0801^{* *}$ & $0.105^{\star * *}$ & $0.0801^{* *}$ & $0.08^{\star *}$ & $0.118^{* * *}$ \\
\hline & [0.0318] & [0.0319] & [0.0318] & {$[0.022]$} & [0.0319] \\
\hline \multirow[t]{2}{*}{$\Delta$ Spread $_{\mathrm{t}-3}$} & -0.00584 & 0.0196 & -0.00584 & -0.004 & 0.0348 \\
\hline & [0.0319] & [0.0319] & [0.0319] & [0.0498] & {$[0.0321]$} \\
\hline \multirow[t]{2}{*}{$\Delta$ Spread $_{\mathrm{t}-4}$} & $-0.0936^{* * *}$ & $-0.0702^{* *}$ & $-0.0936^{\star * *}$ & $-0.102^{* *}$ & -0.0513 \\
\hline & [0.0321] & {$[0.0321]$} & {$[0.0321]$} & {$[0.05]$} & [0.0324] \\
\hline \multirow[t]{2}{*}{$\Delta$ Spread $_{\mathrm{t}-5}$} & 0.0479 & $0.0634^{* *}$ & 0.0479 & 0.05 & $0.0793^{\star *}$ \\
\hline & [0.0313] & {$[0.0311]$} & [0.0313] & [0.0313] & [0.0313] \\
\hline \multirow[t]{2}{*}{ Saudi-Bahrain } & & $0.146^{* * *}$ & & & $0.149^{\star * *}$ \\
\hline & & [0.0369] & & & [0.0368] \\
\hline \multirow[t]{2}{*}{ Saudi-Oman } & & $0.186^{* * *}$ & & & $0.202^{* \star *}$ \\
\hline & & {$[0.0387]$} & & & [0.0388] \\
\hline \multirow[t]{2}{*}{ Saudi-Qatar } & & $0.153^{* * *}$ & & & $0.153^{* * *}$ \\
\hline & & {$[0.0374]$} & & & {$[0.0372]$} \\
\hline \multirow[t]{2}{*}{ Saudi-U.A.E. } & & $0.149^{\star * *}$ & & & $0.146^{\star \star \star}$ \\
\hline & & [0.0372] & & & {$[0.0370]$} \\
\hline \multirow[t]{2}{*}{ Constant } & $0.033^{* * *}$ & $-0.08^{* * *}$ & $0.0325^{\star \star \star}$ & 0.0325 & $-0.0765^{\star * *}$ \\
\hline & {$[0.0110]$} & [0.0253] & {$[0.0110]$} & [0.0295] & {$[0.0252]$} \\
\hline Observations & 955 & 955 & 955 & 955 & 955 \\
\hline R-squared & 0.078 & 0.116 & 0.08 & & 0.12 \\
\hline Hansen test: $p$-value & & & & 1.0 & \\
\hline AR(1): p-value & & & & 0.04 & \\
\hline$A R(2): p$-value & & & & 0.198 & \\
\hline Breusch Pagan p-value & & 0.008 & & & \\
\hline Hausmann LM p-value & & 0.0004 & & & \\
\hline
\end{tabular}

Note: Standard errors in brackets.

${ }^{* * *}$ denotes significant at the 1 percent, ${ }^{* *}$ at the 5 percent, and * at the 10 percent levels. 
Table 9. ECCU: T-Bill Rates Tests of Beta Convergence

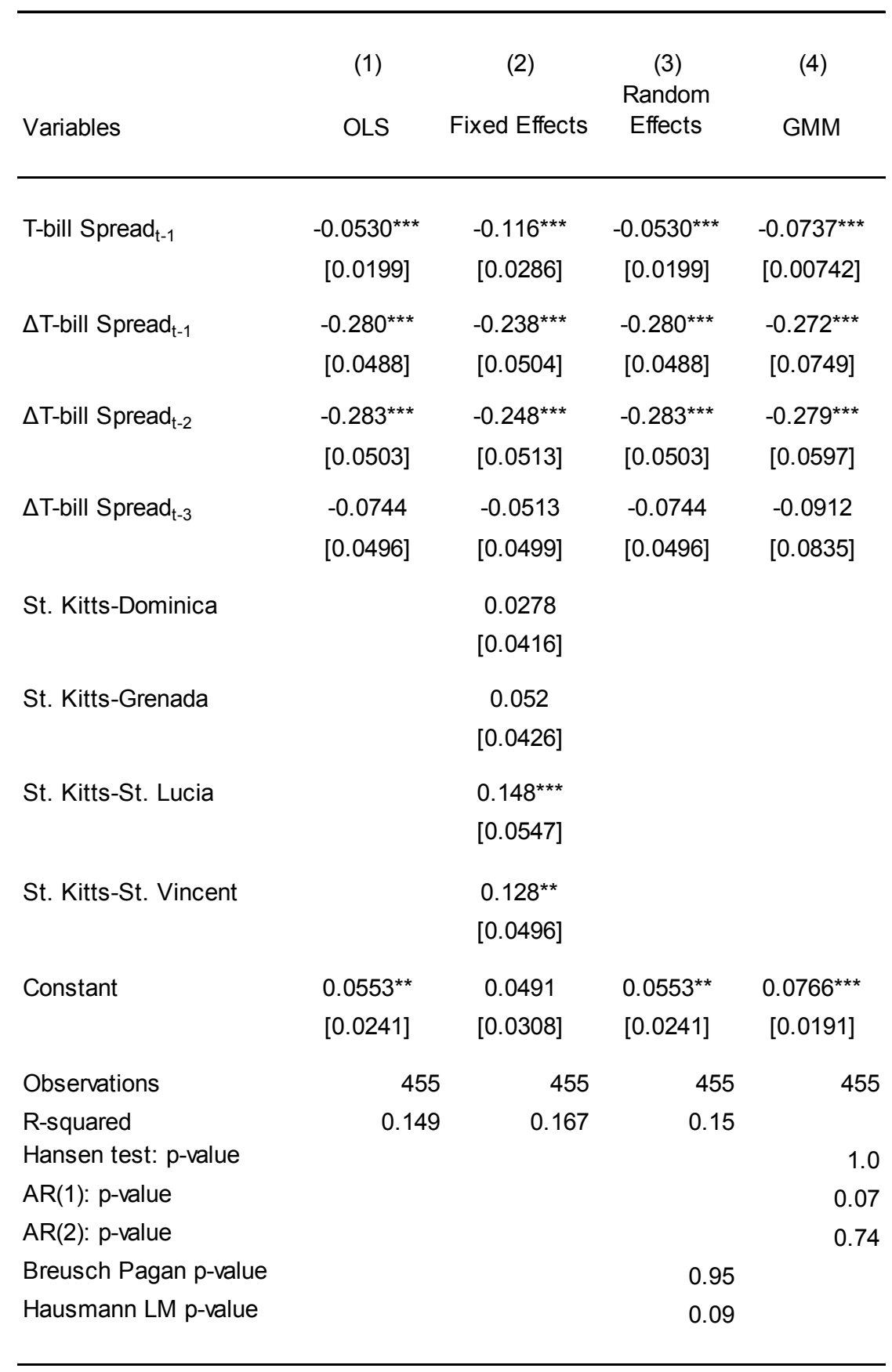

Note Standard errors in brackets

${ }^{* * *}$ denotes significant at the 1 percent, ${ }^{* *}$ at the 5 percent, and ${ }^{*}$ at the 10 percent levels. 
Table 10. ECCU: Deposit Rates Tests of Beta Convergence

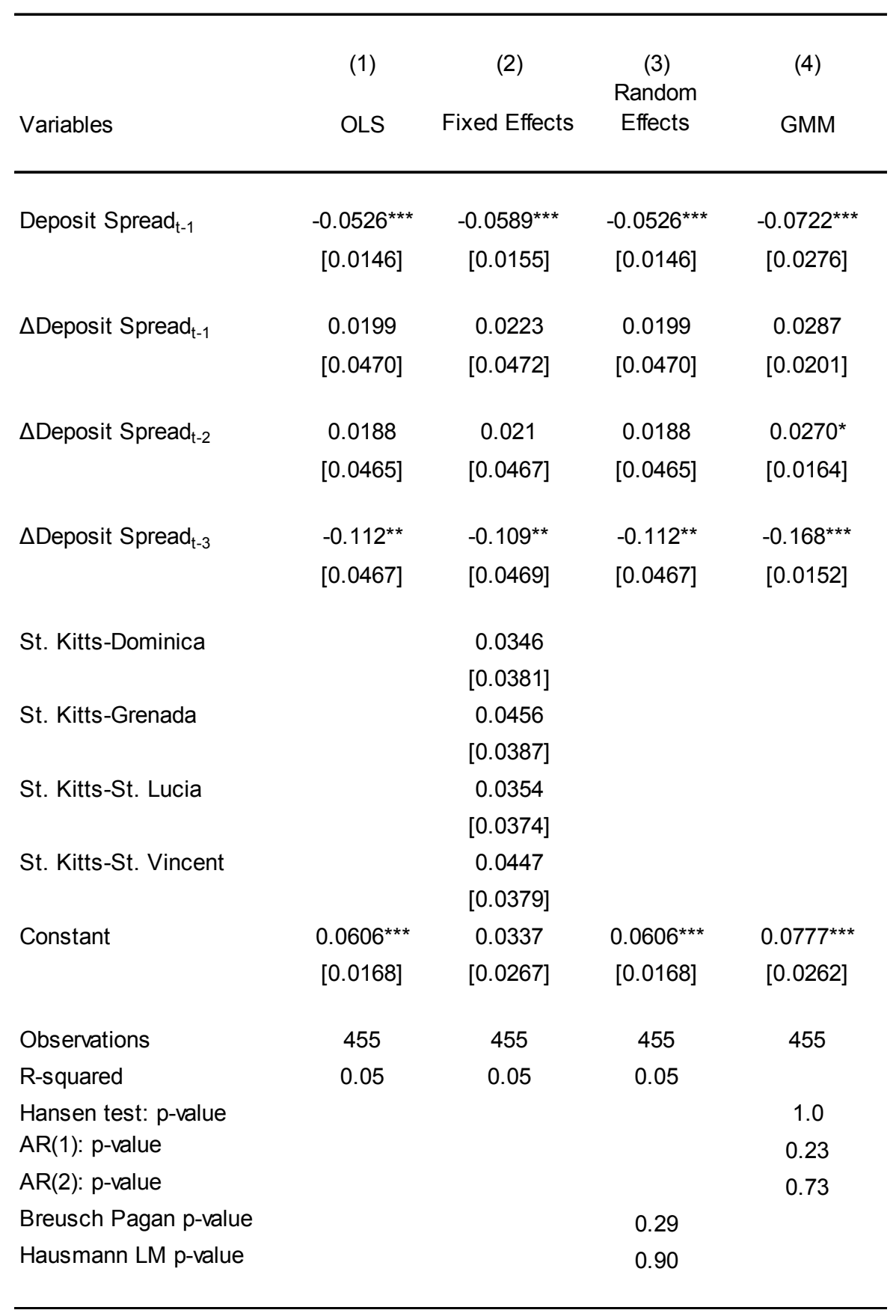

Note Standard errors in brackets

${ }^{* * *}$ denotes significant at the 1 percent, ${ }^{* *}$ at the 5 percent, and * at the 10 percent levels. 
Table 11. ECCU: Lending Rates Tests of Beta Convergence

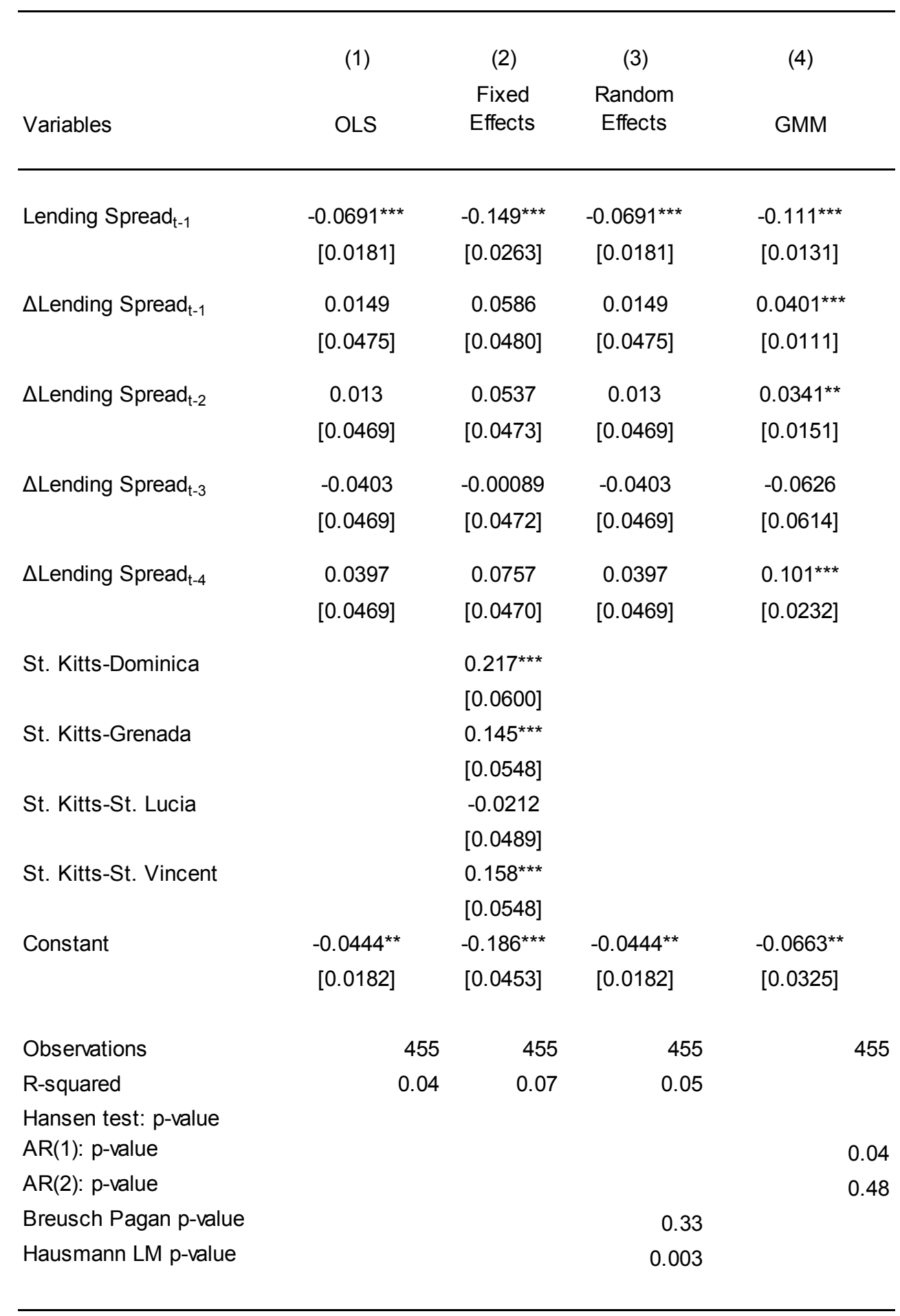

Note: Standard errors in brackets.

*** Denotes significant at the 1 percent, ${ }^{* *}$ at the 5 percent, and * at the 10 percent levels 
Table 12. Selected Sources and Destination of Cross-Listings

\begin{tabular}{|c|c|c|}
\hline Region & Country of origin & No. of cross-listings \\
\hline \multirow[t]{2}{*}{ GCC } & Kuwait to Bahrain & 10 \\
\hline & Qatar to U.A.E. & 2 \\
\hline \multirow[t]{6}{*}{ ASEAN+3 } & China mainland (all to HKG) & 185 \\
\hline & Hong Kong & 8 \\
\hline & Japan & 1 \\
\hline & Malaysia & 1 \\
\hline & Singapore & 1 \\
\hline & Korea & 2 \\
\hline CARICOM & Trinidad and Tobago (authorities' data) & 9 \\
\hline \multirow[t]{8}{*}{ EU and Israel } & Spain(to France) & 3 \\
\hline & France(to Spain) & 2 \\
\hline & Germany (to France) & 4 \\
\hline & France (to Germany) & 400 \\
\hline & Spain (to Germany) & 119 \\
\hline & Euro Area (to UK) & 180 \\
\hline & UK (to Euro Area) & 1943 \\
\hline & Israel (to Euro Area) & 105 \\
\hline Brazil & Brazil (to Argentina) & 1 \\
\hline \multirow[t]{3}{*}{ NAFTA } & Canada (to the U.S.) & 1479 \\
\hline & Mexico (to the U.S.) & 54 \\
\hline & U.S.A. (to Canada) & 41 \\
\hline \multirow[t]{2}{*}{ Pacific Island Forum } & Australia (to New Zealand) & 26 \\
\hline & New Zealand (to Australia) & 21 \\
\hline \multirow[t]{4}{*}{ Others } & India (to Thailand) & 1 \\
\hline & South Africa (to Ghana) & 2 \\
\hline & South Africa (to Namibia) & 30 \\
\hline & South Africa (to Zimbabwe) & 2 \\
\hline
\end{tabular}

Sources: DataStream; and country authorities for GCC and Caribbean markets. 
Table 13. Cross-Listed Stocks in the GCC

\begin{tabular}{|c|c|c|c|c|c|}
\hline Company Name/Country & Start date & End date & $\begin{array}{l}\text { Simultaneous } \\
\text { Trading } \\
\text { Days }\end{array}$ & $\begin{array}{c}\text { No. of Days Since } \\
\text { First Simultaneous } \\
\text { Trading }\end{array}$ & $\begin{array}{l}\text { Average No. of Week } \\
\text { Days Between Two } \\
\text { Simultaneous Trading }\end{array}$ \\
\hline Qatar - Abu-Dhabi & & & & & 4.8 \\
\hline Qatar Telecom (QTel) & 5-Jun-03 & 22-Oct-08 & 291 & 1966 & 4.8 \\
\hline Barhain - Kuwait (avg) & & & & & 3.3 \\
\hline Gulf Finance House (GFH) & 14-Jun-04 & 13-Jul-09 & 881 & 1855 & 1.5 \\
\hline Ithmaar & 7-Apr-08 & 22-Oct-08 & 103 & 198 & 1.4 \\
\hline Ahli United Bank & 29-Oct-06 & 24-Nov-08 & 256 & 757 & 2.1 \\
\hline Arab Insurance Group & 5-Feb-03 & 30-Jul-08 & 249 & 2002 & 5.7 \\
\hline United Gulf Bank (UGB) & 14-May-03 & 26-Nov-08 & 258 & 2023 & 5.6 \\
\hline \multicolumn{6}{|l|}{ Germany-UK } \\
\hline Gulf Finance House (GFH) & 6-Jul-07 & 23-Jun-09 & 390 & 718 & 1.3 \\
\hline \multicolumn{6}{|l|}{ Bahrain-UK } \\
\hline Gulf Finance House (GFH) & 3-Jul-07 & 7-Jul-09 & 308 & 735 & 1.7 \\
\hline \multicolumn{6}{|l|}{ Kuwait-UK } \\
\hline Gulf Finance House (GFH) & 9-Jul-07 & 13-Jul-09 & 356 & 735 & 1.5 \\
\hline Brazil - Argentina & & & & & 1.1 \\
\hline Petrobras & 28-Apr-06 & 11-Jul-07 & 297 & 439 & 1.1 \\
\hline Trinidad and To. - Jamaica (avg) & & & & & 5.4 \\
\hline Trinidad and To. - Barbados (avg) & & & & & 18.5 \\
\hline Hong-Kong - Singapore (avg) & & & & & 2.5 \\
\hline France - Germany (avg) & & & & & 1.2 \\
\hline
\end{tabular}

Sources: Bloomberg; countries' authorities; and authors' calculations. 
Table 14. Arbitrage Opportunities Summary Statistics

\begin{tabular}{|c|c|c|c|c|}
\hline & Mean & Standard Dev. & $10 \%$ percentile & $90 \%$ percentile \\
\hline Qatar - Abu-Dhabi & 4.6 & 3.1 & 1.0 & 8.8 \\
\hline Qatar Telecom (QTel) & 4.6 & 3.1 & 1.0 & 8.8 \\
\hline Barhain - Kuwait (avg) & 2.8 & 2.6 & 0.4 & 5.9 \\
\hline Gulf Finance House (GFH) & 2.6 & 2.6 & 0.3 & 5.7 \\
\hline Ithmaar & 2.4 & 2.2 & 0.3 & 5.5 \\
\hline Ahli United Bank & 2.6 & 2.6 & 0.3 & 5.2 \\
\hline Arab Insurance Group & 2.7 & 2.8 & 0.4 & 5.5 \\
\hline United Gulf Bank (UGB) & 3.4 & 2.9 & 0.5 & 7.7 \\
\hline \multicolumn{5}{|l|}{ Germany-UK } \\
\hline Gulf Finance House (GFH) & 3.3 & 3.9 & 0.2 & 8.1 \\
\hline \multicolumn{5}{|l|}{ Bahrain-UK } \\
\hline Gulf Finance House (GFH) & 6.8 & 6.6 & 1.1 & 17.0 \\
\hline \multicolumn{5}{|l|}{ Kuwait-UK } \\
\hline Gulf Finance House (GFH) & 7.4 & 7.1 & 0.9 & 18.1 \\
\hline Brazil-Argentina & 1.1 & 1.0 & 0.1 & 2.4 \\
\hline Petrobras & 1.1 & 1.0 & 0.1 & 2.4 \\
\hline Trinidad and To. - Jamaica & 6.6 & 5.8 & 0.9 & 13.0 \\
\hline Trinidad and To. - Barbados & 5.2 & 4.1 & 0.9 & 10.3 \\
\hline Hong-Kong - Singapore (avç & 6.2 & 5.4 & 1.0 & 13.1 \\
\hline France - Germany (avg) & 1.2 & 1.2 & 0.1 & 2.6 \\
\hline
\end{tabular}

Source: Authors' calculations. 
Table 15. ARCH Results

\begin{tabular}{|c|c|c|c|c|c|}
\hline & $\begin{array}{l}(a) \\
\beta\end{array}$ & $\begin{array}{l}\text { (b) } \\
\text { regression } \\
\text { half-life 1/ }\end{array}$ & $\begin{array}{c}(\mathrm{c}) \\
\text { week day } \\
\text { half-life 2/ }\end{array}$ & $\begin{array}{c}(\mathrm{d}) \\
\mathrm{ARCH} \text { lag }\end{array}$ & $\begin{array}{c}(\mathrm{e}) \\
\text { GARCH lag }\end{array}$ \\
\hline Qatar - Abu-Dhabi & -0.37 & 1.5 & 7.3 & & \\
\hline Qatar Telecom (QTel) & $-0.37^{* * *}$ & 1.5 & 7.3 & 0.15 & 0.17 \\
\hline Barhain - Kuw ait (avg) & -0.29 & 2.2 & 6.4 & & \\
\hline Gulf Finance House (GFH) & $-0.26^{* * *}$ & 2.3 & 3.1 & $0.09 * * *$ & $0.88^{* * *}$ \\
\hline Ithmaar & $-0.28^{* * *}$ & 2.1 & 2.9 & $0.14^{* *}$ & $0.83^{* * *}$ \\
\hline Ahli United Bank & $-0.19 * * *$ & 3.3 & 7.1 & $0.13^{* *}$ & $0.82 * * *$ \\
\hline Arab Insurance Group & $-0.46^{* * *}$ & 1.1 & 6.5 & 0.03 & 0.47 \\
\hline United Gulf Bank (UGB) & $-0.27^{* * *}$ & 2.2 & 12.2 & 0.30 & 0.43 \\
\hline \multicolumn{6}{|l|}{ Germ any-UK } \\
\hline Gulf Finance House (GFH) 3/ & $-0.94^{* * *}$ & 0.2 & 0.3 & 0.20 ** & $0.81^{* * *}$ \\
\hline \multicolumn{6}{|l|}{ Bahrain-UK } \\
\hline Gulf Finance House (GFH) & $-0.25 * * *$ & 2.4 & 4.2 & 0.41 & $0.644^{* *}$ \\
\hline \multicolumn{6}{|l|}{ Kuw ait-UK } \\
\hline Gulf Finance House (GFH) & $-0.20^{* * *}$ & 3.1 & 4.6 & $0.27^{* * *}$ & $0.777^{* * *}$ \\
\hline Brazil - Argentina & -0.22 & 2.8 & 2.9 & & \\
\hline Petrobras & $-0.22^{* * *}$ & 2.8 & 2.9 & $0.11^{* *}$ & $0.86^{* * *}$ \\
\hline Trinidad and To. - Jam aica (avg) & -0.17 & 3.8 & 18.3 & & \\
\hline Trinidad and To. - Barbados (avg) & -0.28 & 2.2 & 40.3 & & \\
\hline Hong-Kong - Singapore (avg) & -0.22 & 4.3 & 8.4 & & \\
\hline France - Germany (avg) & -0.77 & 0.5 & 0.6 & & \\
\hline
\end{tabular}

$1 / \ln (1 / 2) / \ln (1+\beta)$.

$2 / \ln (1 / 2) / \ln (1+\beta)^{*}(n$.of days betw een simultaneous trading $)$.

3/ The AR model for this listing does not include a constant (the model with constant generated a $\beta$ low er than -1 ). 
Table 16. Threshold AR Results

\begin{tabular}{|c|c|c|c|c|c|}
\hline & $\begin{array}{l}\text { (a) } \\
\mathrm{c}\end{array}$ & $\begin{array}{l}\text { (b) } \\
\text { bin }\end{array}$ & $\begin{array}{l}\text { (c) } \\
\text { bout }\end{array}$ & $\begin{array}{c}(\mathrm{d}) \\
\mathrm{ARCH} \text { lag }\end{array}$ & $\begin{array}{c}(\mathrm{e}) \\
\text { GARCH lag }\end{array}$ \\
\hline Qatar - Abu-Dhabi & 2 & -0.80 & -0.47 & & \\
\hline Qatar Telecom (QTel) & 2 & -0.80 & $-0.47^{\star \star *}$ & 0.18 & 0.26 \\
\hline Barhain - Kuw ait (avg) & 0.6 & -0.36 & -0.33 & & \\
\hline Gulf Finance House (GFH) & 0.3 & 0.05 & $-0.29 * * *$ & $0.09 * * *$ & $0.89^{* * *}$ \\
\hline Ithmaar & 0.7 & 0.41 & $-0.35 * * *$ & $0.15^{* *}$ & $0.83^{* * *}$ \\
\hline Ahli United Bank & 1.4 & 0.36 * & $-0.26^{* * *}$ & $0.13^{* *}$ & $0.83^{* * *}$ \\
\hline Arab Insurance Group & 0.2 & -1.68 & $-0.48 * * *$ & 0.03 & 0.45 \\
\hline United Gulf Bank (UGB) & 0.3 & -0.93 & $-0.29 * * *$ & 0.31 & 0.42 \\
\hline \multicolumn{6}{|l|}{ Germany-UK } \\
\hline Gulf Finance House (GFH) & 0.3 & 1.09 & $-0.97^{* * *}$ & $0.15^{* *}$ & $0.86^{* * *}$ \\
\hline \multicolumn{6}{|l|}{ Bahrain-UK } \\
\hline Gulf Finance House (GFH) & 17.0 & $-0.23^{* * *}$ & $-1.34^{* * *}$ & 0.31 ** & $0.71^{* \star *}$ \\
\hline \multicolumn{6}{|l|}{ Kuw ait-UK } \\
\hline Gulf Finance House (GFH) & 15.7 & $-0.20 * * *$ & -0.45 & $0.57 * * *$ & $0.41^{* * *}$ \\
\hline Brazil - Argentina & 1.8 & -0.40 & -0.20 & & \\
\hline Petrobras & 1.8 & $-0.40^{* * *}$ & -0.21 & $0.12^{* * *}$ & $0.86^{* * *}$ \\
\hline Trinidad and To. - Jamaica (avg) & 8.1 & -0.06 & -0.43 & & \\
\hline Trinidad and To. - Barbados (avg & 5.2 & 5.81 & -0.68 & & \\
\hline Hong-Kong - Singapore (avg) & 4.7 & -0.84 & -0.30 & & \\
\hline France - Germ any (avg) & 0.1 & -12.22 & -0.80 & & \\
\hline
\end{tabular}

1/ The AR model for this listing does not include a constant (the model w ith constant generated a $\beta$ low er than -1 ). 